\title{
Difficulties in diagnosing the cause of hyponatraemia in an extremely premature boy
}

\author{
Aleksandra Bryłka', Omar Bjanid'1, Wojciech Korlacki², Maria Nowak³, Marta Nowak, \\ Marcela Sobecka ${ }^{3}$, Majka Jaszczura ${ }^{4}$, Piotr Adamczyk ${ }^{5}$, Maria Szczepańska ${ }^{5}$ \\ 'Department of Paediatric Nephrology, Teaching Hospital No. 1, Medical University of Silesia, Zabrze, Poland \\ ${ }^{2}$ Department of Paediatric Malformations Surgery and Traumatology, Teaching Hospital No. 1, Medical University of Silesia, \\ Zabrze, Poland \\ ${ }^{3}$ Students' Scientific Circle at the Department and Clinic of Paediatrics, Teaching Hospital No. 1, Medical University of Silesia, \\ Zabrze, Poland \\ ${ }^{4}$ Department of Paediatrics, Teaching Hospital No. 1, Medical University of Silesia, Zabrze, Poland \\ ${ }^{5}$ Chair and Department of Paediatrics, School of Medicine with the Division of Dentistry in Zabrze, Medical University \\ of Silesia, Zabrze, Poland
}

\section{ABSTRACT}

We present the history of a nine-month-old male infant born prematurely with extremely low birth weight, who was admitted to the paediatric nephrology department with dehydration, acute kidney injury, hyponatraemia, hyperkalaemia, and metabolic acidosis. While the crucial first step in the diagnosis of hyponatraemia includes the assessment of the patient's fluid status, we focus in the discussion on the causes, diagnosis, and treatment of hypovolemic hyponatraemia. With the notable exception of congenital adrenal hyperplasia $(\mathrm{CAH})$ and other primary adrenal diseases, in which there is a deficiency in aldosterone synthesis, many other salt-losing disorders share the common feature of inducing secondary hyperaldosteronism. In the presented case hyponatraemia was caused by NEC-related ileostomy with, typically, hyperkalaemia despite secondary hyperaldosteronism. The clinical picture can be very similar to pseudohypoaldosteronism type 1 (PH 1), with the renal handling of sodium being the key differentiating feature.

\section{KEY WORDS:}

prematurity, hyponatraemia, ileostomy, pseudohypoaldosteronism type 1.

\section{INTRODUCTION}

Hyponatraemia and dehydration are potentially serious threats to the health and life of young children. In infants, especially those born prematurely, the regulatory mechanisms of homeostasis are not fully developed yet, and therefore water and electrolyte imbalances can occur faster and have a more severe course than in older children. Clinical symptoms of hyponatraemia are non-specific, and their severity depends on the onset dynamic of the distur- bance. Chronic hyponatraemia may be less expressed or even asymptomatic. The spectrum of possible symptoms of hyponatraemia consist of nausea, vomiting, headaches (in older children), and alteration of consciousness. When the disorders exacerbate, cerebral oedema and hypoxia occur and manifest through emesis, convulsions, bradycardia, and, in extreme cases, respiratory distress and coma [1].

Dehydration in children, which often occurs together with disturbances in sodium balance, is characterised by dryness of the mucosa, sunken eyes, reduced skin turgor

\section{ADDRESS FOR CORRESPONDENCE:}

Aleksandra Bryłka, Department of Paediatric Nephrology, Teaching Hospital No. 1, Medical University

of Silesia, Zabrze, 13-15 3 Maja St., 41-800 Zabrze, Poland, e-mail: brylkaalex@gmail.com 
and body weight, tachycardia, and sunken fontanelle in infants [2]. In the case of hypovolemic hyponatraemia the management is focused on rehydration, correction of the sodium deficiency, and, if possible, treatment of the underlying disease. While dehydration in children is most frequently caused by acute gastrointestinal infections, numerous other less common endocrine, renal, or gastrointestinal conditions can cause sodium loss and hypovolaemia, and are discussed in the differential diagnosis of the presented case.

\section{CASE REPORT}

A nine-month-old male infant was admitted to the Department of Paediatric Nephrology in Zabrze due to electrolyte disturbances. The boy was born prematurely in the $25^{\text {th }}$ week of pregnancy from a preterm spontaneous vaginal delivery, with extremely low birth weight (760 g). He received 5/6/6/6 points in the Apgar scale. The pregnancy was complicated with maternal urinary tract infection and marginal placenta praevia. Spotting and vaginal bleeding occurred from the $12^{\text {th }}$ week of gestation, and progesterone and lutein were administered to maintain the pregnancy. Two days before delivery a fever occurred in the mother caused by urinary tract infection. The delivery was complicated with perinatal hypoxia and intracranial $4^{\text {th }}$ grade haemorrhage. The newborn required mechanical ventilation due to respiratory distress. Screening tests for metabolic diseases and, notably, cystic fibrosis were negative.

In the second month of life, the boy was operated due to gastrointestinal tract obstruction, caused by a persistent meconium plug located in the distal ileum, which was evacuated. In the third month of life another episode of obstruction occurred accompanied by necrotising enterocolitis (NEC) and perforation. Faecal peritonitis was observed intraoperatively, with a necrotic and perforated ileal segment located $10 \mathrm{~cm}$ before the ileocaecal valve.

TABLE 1. Results of selected parameters performed on admission to the nephrology department for children

\begin{tabular}{|l|c|c|}
\hline $\begin{array}{l}\text { Laboratory } \\
\text { parameter }\end{array}$ & Result & Reference range \\
\hline eGFR & $58 \mathrm{ml} / \mathrm{min}$ & $40-90 \mathrm{ml} / \mathrm{min} / 1.73 \mathrm{~m}^{2}$ \\
\hline In blood & $24.2 \mathrm{mmol} / \mathrm{l}$ & $21-27 \mathrm{mmol} / \mathrm{l}$ \\
\hline $\mathrm{HCO}_{3}$ & $18.6 \mathrm{mmol} / \mathrm{l}$ & $1.43-6.78 \mathrm{mmol} / \mathrm{l}$ \\
\hline Urea & $35 \mu \mathrm{mol} / \mathrm{l}$ & $15-37 \mu \mathrm{mol} / \mathrm{l}$ \\
\hline Creatinine & $795 \mathrm{pg} / \mathrm{ml}$ & $17.6-232 \mathrm{pg} / \mathrm{ml}$ \\
\hline Aldosterone & $65 \mathrm{ng} / \mathrm{ml} / \mathrm{h}$ & $2.4-35 \mathrm{ng} / \mathrm{ml} / \mathrm{h}$ \\
\hline Plasma renin activity & \\
\hline 24-hour urine collection & $19.21 \mathrm{mg} / 24 \mathrm{~h}$ & $0-30 \mathrm{mg} / 24 \mathrm{~h}$ \\
\hline Albumin & $127.2 \mu \mathrm{g} / 24 \mathrm{~h}$ & $6-34 \mu \mathrm{g} / 24 \mathrm{~h}$ \\
\hline THAldo
\end{tabular}

Fifteen centimetres of the necrotic small intestine was resected and a double-barrelled ileostomy performed. The patient's condition after surgery was severe, and he again required mechanical ventilation for one week. During the postoperative period in the paediatric ICU periodical convulsions and myoclonus were observed.

Additional disorders related in part to prematurity were also diagnosed: respiratory distress syndrome (RDS), chronic lung disease (CLD), persistent pulmonary hypertension of the newborn (PPHN), emphysema, and oesophagitis, which led to the perforation of the oesophagus in the fourth week of life and the formation of oesophagopleural fistula with mediastinal inflammation. The last complication was treated conservatively. The child was also diagnosed with transient liver failure, cholestasis, systemic inflammatory response syndrome (SIRS), anaemia, thrombocytopaenia, retinopathy of prematurity, dilatation of the inguinal canal, and bilateral hydrocele.

After stabilisation and discharge from the hospital, the infant was subsequently hospitalised five times due to dehydration and electrolyte disturbances, mainly hyponatraemia. The lowest recorded sodium concentration value was $117.9 \mathrm{mmol} / \mathrm{l}$.

During hospitalisation in the nephrology department (at the age of nine months) the physical examination revealed features of dehydration of more than $10 \%$ of body weight. Laboratory tests showed hyponatraemia (124 mmol/l), hyperkalaemia $(6.15 \mathrm{mmol} / \mathrm{l})$, compensated metabolic acidosis, and eGFR of $58 \mathrm{ml} / \mathrm{min} / 1.73 \mathrm{~m}^{2}$. The inflammatory markers were negative and the urinalysis was normal. The fractional excretion of sodium ( $\mathrm{FeNa}$ ) was $0.02 \%$ and consistently low, which allowed kidney sodium loss to be ruled out. Serum aldosterone level and plasma renin activity were elevated $(795 \mathrm{pg} / \mathrm{ml}$ and $65 \mathrm{ng} / \mathrm{ml} / \mathrm{h}$, respectively). ACTH and cortisol secretion were in the normal range (respective morning values of $63 \mathrm{pg} / \mathrm{ml}$ and $10 \mu \mathrm{g} / \mathrm{dl}$, and night values of $14 \mathrm{pg} / \mathrm{ml}$ and $2.8 \mu \mathrm{g} / \mathrm{dl}$ ). An increased excretion of tetrahydro-aldosterone was found in a 24-hour urine collection (THAldo study was performed in the Children's Memorial Health Institute, Department of Biochemistry, Radioimmunology, and Experimental Medicine) (Table 1). A sweat chloride test was also carried out, and was normal. No abnormalities were found at abdominal ultrasound, with notably a normal kidney and urinary tract appearance.

On the basis of those findings, kidney tubular disorders and endocrine causes of hyponatraemia were excluded, and a diagnosis of high drainage ileostomy related dehydration, salt loss, and secondary hyperaldosteronism was established.

After clinical stabilisation the child was discharged for further ambulatory follow-up with the prescription of oral sodium chloride and sodium bicarbonate supplementation. The follow-up electrolyte values and gas acid-base balance results were satisfactory with periodical dose adjustments. 
At the age of 17 months an attempt to restore the continuity of the gastrointestinal tract was made. Due to the significant ileal lumen disproportion, anastomosis was performed side to side. In the postoperative period symptoms of intestinal obstruction were observed and required reoperation with a further resection of $15 \mathrm{~cm}$ of the small intestine along with the previous anastomosis and cecum with the ileocecal valve. A double layer endto-end ileocolic anastomosis was performed and proved to be efficient. After this second operation no further complications were observed, with effective restoration of the natural route of defecation. The boy's subsequent follow-up is unknown because he did not attend control visits.

The graphs show changes in body weight (Fig. 1) and changes in the serum concentration of sodium and potassium (Fig. 2) within the available period of observation lasting for eight months.

\section{DISCUSSION}

Mild transient hyponatraemia is observed quite frequently in infants and does not constitute a threat to their health [3]. In the case of relapsing or chronic hyponatraemia, especially when the sodium concentration values are less than $130 \mathrm{mmol} / \mathrm{l}$, a thorough workup and comprehensive differential diagnosis is warranted. The kidneys play a central role in the sodium homeostasis, notably by excreting $95 \%$ of the dietary sodium load. Thus recurrent water-electrolyte disturbances suggest a possible primary or secondary impairment of renal function [4]. By comparison, the digestive tract and the skin excrete, respectively, $4.5 \%$ and $0.5 \%$ of the sodium load. An excessive loss of sodium by any of the three above-mentioned systems can lead to volume depletion, which in turn can stimulate the non-osmotic release of antidiuretic hormone $(\mathrm{ADH})$ and water conservation, and enhance the hyponatraemia in consequence. Renal salt and water depletion can occur in tubular disorders, or may be caused by osmotic diuresis or diuretics. With regard to the gastrointestinal (GI) tract, hypovolaemic hyponatraemia can occur in result of diarrhoea, vomiting, intestinal obstruction, and fistulas.

Although hypovolaemic hyponatraemia is the most common dysnatraemia in paediatric patients, sodium concentration disturbances are by no means obligatory associated with hypovolaemia. They merely reflect a disproportion between water and sodium in the extracellular fluid compartment, and can occur with only subtle or no alteration of volaemia, or in oedematous, overtly hypervolaemic states, like cardiac or liver failure and nephrotic syndrome [1]. Common causes of normovolaemic hyponatraemia are inadequate secretion of antidiuretic hormone, hypothyroidism, and adrenocortical insufficiency.

Premature infants are particularly prone to developing hyponatraemia, due to several factors like reduced sodi-

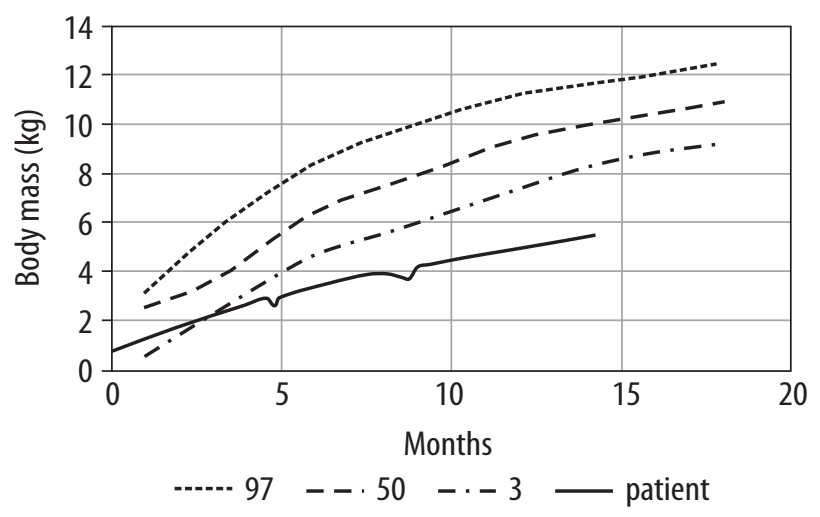

FIGURE 1. The weight gain shown in centile chart during 8 months of follow-up

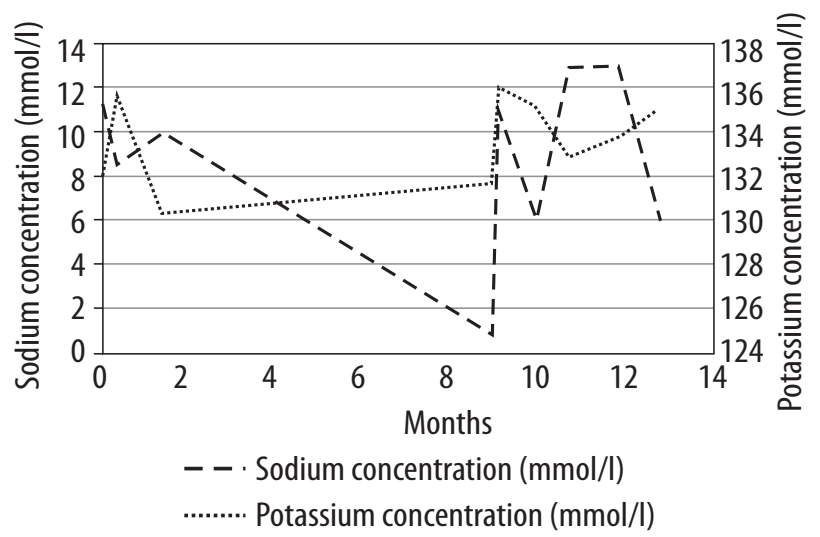

FIGURE 2. Sodium and potassium concentrations during 8-month observation

um reabsorption in the proximal and distal renal tubule, limited salt supply, e.g. during breastfeeding, and immaturity of other water-electrolyte homeostasis mechanisms [3]. Acute GI complications such as NEC constitute an additional challenge to homeostasis in that population. A temporary ileostomy is a recognised treatment modality in newborns with acute abdomen, most often NEC [5]. The length of the small intestine in full-term newborns is estimated at about $2.5-3 \mathrm{~m}$, in premature children it can be even half of that length. The minimal small intestine length after resection necessary for feeding autonomy, and thus a major determinant of parenteral feeding dependency and survival prognosis, is estimated at $15 \mathrm{~cm}$ if the ileocaecal valve is preserved, and $40 \mathrm{~cm}$ otherwise [5]. In infants with ileostomy fed enterally, high output stoma (secretion of more than $50 \mathrm{ml} / \mathrm{kg} /$ day) is often observed, and can lead to a shift in the proportion of sodium excreted by the digestive tract and the kidneys [6]. Due to the immaturity of the kidneys that hampers their capacity to compensate the increased extrarenal salt waste, even a small increase in enteral input can stimulate secretion and lead to high watery stoma output with dehydration and electrolyte depletion [7]. Another complication in ileostomy-related sodium depletion is the observed poor weight gain despite adequate caloric intake [8]. The mechanism of the sodium depletion impact on weight is still unclear; however, some studies have suggested ineffec- 
tive glucose absorption due to impaired sodium-glucose co-transportation through SGLT-1 as a possible cause [8]. According to performed studies ostomy closure and restoration of continuity of the intestinal tract resolved the chronic diarrhoea and reduced susceptibility to electrolyte imbalance [9].

When the mechanism of water and salt depletion is different from primary mineralocorticoid deficiency, compensatory hyperaldosteronism is expected. Not surprisingly, in patients with ileostomy elevated aldosterone and $18-\mathrm{OH}$-corticosterone are reported, as was also the case in the presented patient [10]. What can be surprising, on the other hand, is the frequently observed hyperkalaemia despite secondary hyperaldosteronism in those patients. At least three factors contribute to this status. First, the nature of dyselectrolitaemia in GI tract disorders is determined by the composition of the wasted fluid. Ileostomy drainage contains relatively small amounts of potassium ( $5 \mathrm{mmol} / \mathrm{l}$ ) and high sodium (40-90 mmol/l), compared to other GI fluids (for example: in normal stool the sodium concentration is $20-30 \mathrm{mmol} / \mathrm{l}$ and potassium concentration is $55-75 \mathrm{mmol} / \mathrm{l}$, whereas in inflammatory diarrhoea expected concentrations for sodium and po- tassium are 50-100 $\mathrm{mmol} / \mathrm{l}$ and $15-20 \mathrm{mmol} / \mathrm{l}$, respectively) [11]. Second, metabolic acidosis is often observed (despite hyperaldosteronism) and it is caused by the loss of high amounts of bicarbonate in the ileostomy fluid. Acidosis promotes potassium shift from the intracellular to the extracellular compartment and this transmineralisation leads to hyperkaliaemia. And finally, the third factor is the impaired renal excretion of potassium in the distal tubule, caused by volume depletion in conjunction with the flow dependency of the sodium epithelial channel (ENaC). Despite its up-regulation by aldosterone, the $\mathrm{ENaC}$ activity is limited by the diminished urine flow in the distal tubule, and cannot build up a sufficient electro-negative gradient in the tubule lumen, necessary to excrete $\mathrm{K}+$ and $\mathrm{H}+$ effectively [12].

The differential diagnosis of chronic hyponatraemia in infants must include salt wasting syndromes related to congenital or acquired insufficient synthesis or function of aldosterone. Congenital defects of adrenal biosynthesis are the most common causes, including congenital adrenal hyperplasia $(\mathrm{CAH})$, which is in $90 \%$ of cases due to 21-hydroxylase deficiency [13] and in 75\% is manifested as the classic type with salt loss. Laboratory findings in

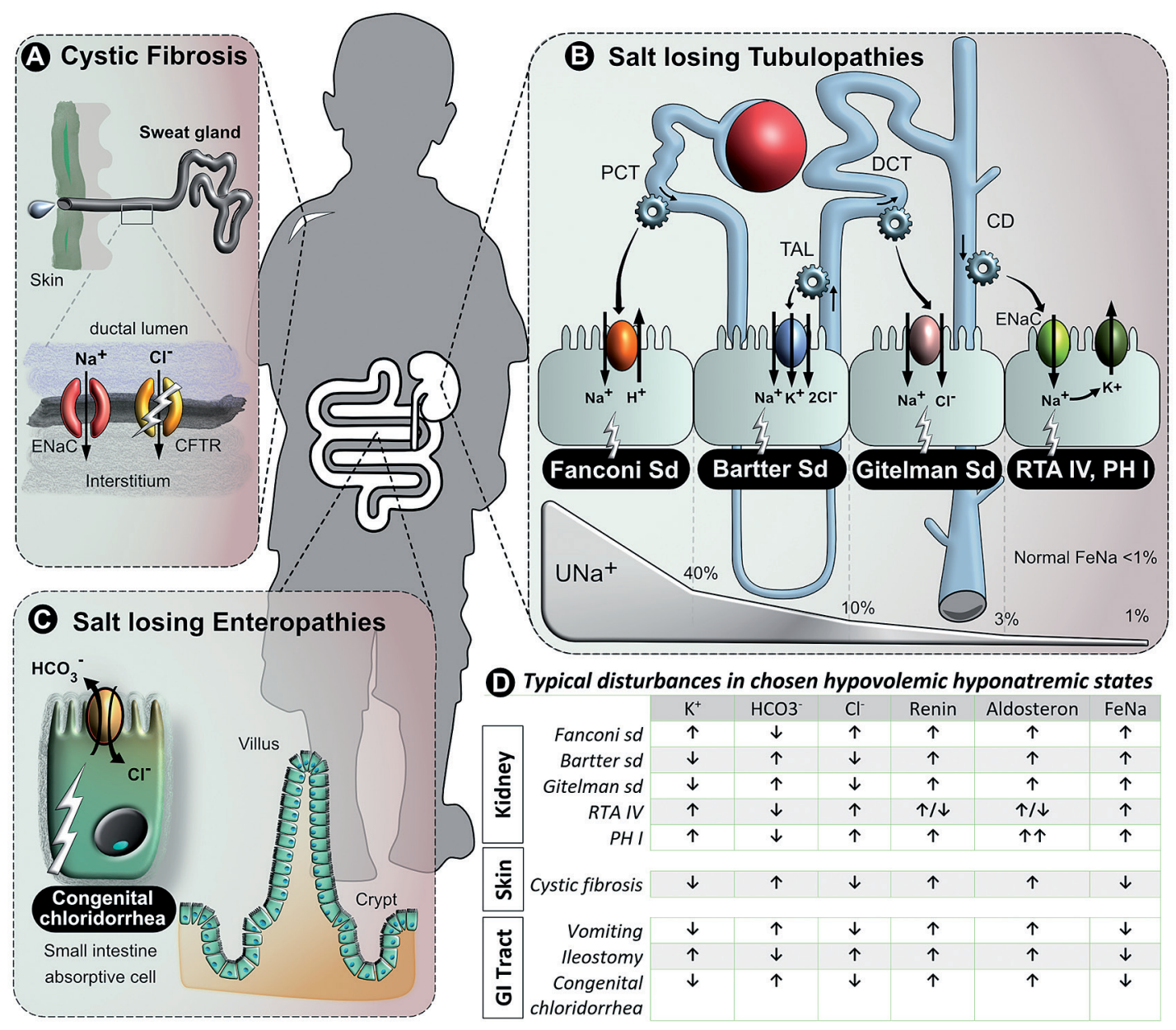

ENaC - epithelial sodium channel, CFTR - cystic fibrosis transmembrane conductance regulator, PCT - proximal convoluted tubule, TAL - thick ascending loop, DCT - distal convoluted tubule, CD - collecting duct, RTA IV - renal tubular acidosis type IV (hyperkalaemic), PH I - pseudohypoaldosteronism type I, Una - urine sodium, FeNa - fractional excretion of sodium

FIGURE 3. The differential diagnosis of salt-loss disorders 
CAH include significant deficiency of cortisol and aldosterone and elevated levels of androgens $[1,14]$.

In the discussed case the levels of cortisol and ACTH were in the normal range at presentation, which made a diagnosis of $\mathrm{CAH}$ highly improbable. Adrenal disorders were definitively ruled out in the ulteriorly obtained urinary steroid profile results. The patient had also high aldosterone, high plasma renin activity, and elevated level of tetrahydroaldosterone (TH-aldo) in urine, which raised the suspicion of pseudohypoaldosteronism type 1 (PH1) [15]. In this disorder renal salt wasting, dehydration, hyperkalaemia, and metabolic acidosis are present, as well as failure to thrive $[16,17]$. The milder, autosomal dominant (adPH1), renal type of the disease is caused by an inactivating mutation of the mineralocorticoid receptor (MR), whereas the more severe, autosomal recessive (arPH1), generalised form of PH1 is caused by a loss of function mutation of the effector, the epithelial sodium channel $(\mathrm{ENaC})$. The clinical course of arPH1 is worse, and spontaneous improvement does not occur [18]. This type is associated with the risk of death immediately after birth. A number of other non-genetic, mainly urologic causes of injury to the distal tubule, such as urinary tract anomalies, urinary tract infections [19], amyloidosis, and tubulo-interstitial injury after kidney transplantation, can cause a state of - usually transient - renal insensitivity to aldosterone [18].

Despite the presence of symptoms suggestive of arPH1, this diagnosis was excluded in our patient, because of the consistently low concentrations of sodium in the urine, with a fractional excretion of sodium (FENa) of persistently less than $1 \%$, which ruled out a renal cause of the salt loss. In cystic fibrosis (CF) salt depletion can occur via the skin, but manifests usually as a Bartter-like syndrome, with alkalosis and hypokalaemia. We did, however, actively exclude CF in genetic and chloride sweat tests because, among other symptoms, the recurrent episodes of GI tract obstruction and meconium plug were observed. After ruling out renal and skin salt waste, the cause of hyponatraemia was established as high output NEC-related ileostomy with, typically, hyperkalaemia despite secondary hyperaldosteronism.

Salt wasting disorders that can cause hypovolemic hyponatraemia are summarised in Figure 3.

\section{DISCLOSURE}

The authors declare no conflict of interest.

\section{REFERENCES}

1. Smyczyńska J, Hilczer M. Zespół utraty soli. In: Stany nagłe. Pediatria. Tkaczyk M (Ed.). Medical Tribune Polska, Warszawa 2015: 306-312.

2. Celińska-Cedro D, Jankowska I, Oracz G, et al. Choroby układu pokarmowego. In: Pediatria. Podręcznik do Lekarskiego Egzaminu
Końcowego i Państwowego Egzaminu Specjalizacyjnego. Dobrzańska A, Ryżko J (Eds.). Elsevier Urban \& Partner, Wrocław 2014: 439-512.

3. Abelian A, Ghinescu CE. Premature baby with extreme hyponatraemia (95 mmol per litre): a case report. BMC Pediatr 2015; 15: 121.

4. Kokot F, Franek E. Zaburzenia gospodarki wodno-elektrolitowej. In: Zaburzenia gospodarki wodno-elektrolitowej i kwasowo-zasadowej. Kokot F, Franek E (Eds.). PZWL, Warszawa 2013: 5-160.

5. Batra A, Beattie RM. Management of short bowel syndrome in infancy. Early Hum Dev 2013; 89: 899-904.

6. Lee J, Kang MJ, Kim HS, et al. Enterostomy Closure Timing for Minimizing Postoperative Complications in Premature Infants. Pediatr Neonatol 2014; 55: 363-368.

7. Smith N, Harwood R, Almond S. Short bowel syndrome - surgical perspectives and outcomes. Paediatr Child Health 2014; 24: 513518.

8. O’Neil M, Teitelbaum DH, Harris MB. Total Body Sodium Depletion and Poor Weight Gain in Children and Young Adults With an Ileostomy: A Case Series. Nutr Clin Pract 2014; 29: 397-401.

9. Struijs MC, Poley MJ, Meeussen CJ, et al. Late vs early ostomy closure for necrotizing enterocolitis: analysis of adhesion formation, resource consumption, and costs. J Pediatr Surg 2012; 47: 658-664.

10. Huber FX, Lucas M, Stern J, et al. Changes in glucocorticoid and mineralocorticoid hormone levels due to compensation for ileostomy losses. Int J Surg Investig 2001; 2: 369-375.

11. Charney AN, Donowitz M. Gastrointestinal influences on hydrogen ion balance. In: Acid-Base Disorders and Their Treatment. Gennari FJ, Adrogue HJ, Galla JH, Madias NE (Eds.). Taylor \& Francis, Boca Raton 2005: 209-240.

12. Gennari J, Weise W. Acid-Base Disturbances in Gastrointestinal Disease. Clin J Am Soc Nephrol 2008; 3: 1861-1868.

13. Bizzarri C, Olivini N, Pedicelli S, et al. Congenital primary adrenal insufficiency and selective aldosterone defects presenting as salt wasting in infancy: a single center 10 year experience. Ital J Pediatr 2016; $42: 73$.

14. Oświęcimska J. Choroby kory nadnerczy. In: Pediatria. Vol. II. Dyduch A (Ed.). Śląski Uniwersytet Medyczny, Katowice 2009: 308-328.

15. Attia NA, Marzouk YI. Pseudohypoaldosteronism in a Neonate Presenting as Life Threatening Hyperkalemia. Pseudohypoaldosteronism in a Neonate Presenting as Life Threatening Hyperkalemia. Case Rep Endocrinol 2016; 2016: 6384697.

16. Szalecki M, Wójcik E, Domagała Z, et al. Pseudohipoaldosteronizm u niemowląt jako przyczyna zespołu utraty soli. Opis dwóch przypadków. Endokrynol Diab Chor Przem Mat Wieku Rozw 2007; 13: 33-36.

17. Bangash AS, Ali NF, Sami S, et al. Pseudohypoaldosteronism Type I: a rare cause of hyperkalemia in neonates. JPMA 2014; 64: 465-467.

18. Smyczyńska J, Lewiński A. Zaburzenia gospodarki wodno-sodowej w przebiegu endokrynopatii u dzieci. Część II. Zaburzenia wydzielania i działania mineralokortykosteroidów. Endokrynol Ped 2012; 1: 71-82.

19. Krishnappa V, Ross JH, Kenagy DN, et al. Secondary or Transient Pseudohypoaldosteronism Associated With Urinary Tract Anomaly and Urinary Infection: A Case Report. Urol Case Rep 2016; 8: 61-62. 